\title{
Phaselicystis flava gen. nov., sp. nov., an arachidonic acid-containing soil myxobacterium, and the description of Phaselicystidaceae fam. nov.
}

\author{
Ronald O. Garcia, ${ }^{1}$ Hans Reichenbach, ${ }^{2}$ Michael W. Ring ${ }^{1}$ and Rolf Müller ${ }^{1}$ \\ ${ }^{1}$ UdS - Department of Pharmaceutical Biotechnology, Saarland University, D-66041 Saarbrücken, \\ Germany \\ ${ }^{2} \mathrm{HZI}$ - Helmholtz-Zentrum für Infektionsforschung GmbH, Inhoffenstraße 7, D-38124 \\ Braunschweig, Germany
}

\begin{abstract}
A bacterial strain designated SBKo001 ${ }^{\top}$ was isolated from a forest soil sample from Mt Makiling in Laguna, Philippines. It shows the general characteristics associated with myxobacteria, such as swarming of Gram-negative, rod-shaped vegetative cells, fruiting body formation and bacteriolytic activity. The strain is mesophilic, strictly aerobic and chemoheterotrophic and also exhibits resistance to various antibiotics. Major fatty acids are iso- $\mathrm{C}_{15: 0}, \mathrm{C}_{17: 1} 2-\mathrm{OH}$ and $\mathrm{C}_{20: 4}$ (arachidonic acid). The $\mathrm{G}+\mathrm{C}$ content of the genomic DNA is $69.2 \mathrm{~mol} \%$. A reference strain, NOSO-1 (=DSM 53757), isolated from the Etosha Basin in Namibia, shares nearly the same characteristics with SBKo001 ${ }^{\top}$. The identical 16S rRNA gene sequences of the two strains show $94 \%$ identity to strains of the cellulose-degrading Byssovorax and Sorangium species.

Phylogenetic analysis reveals a novel branch diverging from the Polyangiaceae, Sorangiineae, Myxococcales. Their uniqueness in morphological growth stages, unusual fatty acid profile, broad-spectrum antibiotic resistance and branch divergence from the Polyangiaceae imply that strains SBKo001 ${ }^{\top}$ and NOSO-1 not only represent a novel genus and species, proposed here as Phaselicystis flava gen. nov., sp. nov., but also belong to a new family, Phaselicystidaceae fam.

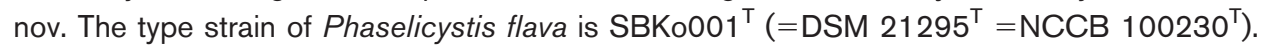

\section{INTRODUCTION}

Myxobacteria are sophisticated and highly social prokaryotes. Cells move by swarming on the surface of the substrate. Under nutrient-limiting conditions, they start to aggregate, leading to the formation of multicellular and complex fruiting bodies. The only known organisms with similar lifestyles are the eukaryotic cellular slime moulds, the dictyosteliomycetes (Brazill \& Gomer, 2007). Myxobacteria are grouped within the Deltaproteobacteria, alongside Bdellovibrio and strictly anaerobic sulfate reducers (Shimkets et al., 2006). Three suborders and five families are recognized to cover most of the known species (Reichenbach, 2005). This study proposes a new taxon for the forest soil isolate SBKo001 ${ }^{\mathrm{T}}$ from the Philippines based on phenotypic, chemotaxonomic and phylogenetic analyses performed together with a reference strain (NOSO-1) from Namibia.

Abbreviation: PUFA, polyunsaturated fatty acid.

The GenBank/EMBL/DDBJ accession number for the $16 \mathrm{~S}$ rRNA gene sequence of strain $\mathrm{SBKo001}{ }^{\top}$ is EU545827.

Further images of various growth phases of strains $\mathrm{SBK}_{0001^{\top}}$ and NOSO-1 are available as supplementary material with the online version of this paper.

\section{METHODS}

Myxobacterial strains. SBKo001 ${ }^{\mathrm{T}}$ was isolated in December 2006 in the Philippines from a soil sample containing decaying leaves and rotting wood pieces from the tropical Mt Makiling Forest Reserve in Laguna Province. The soil was processed immediately after collection using the standard method for the isolation of cellulose degraders on mineral salts agar ST21 overlaid with filter paper (Reichenbach \& Dworkin, 1992). The strain was noticed first along the edges of the filter paper as small and yellow fruiting bodies with flattened kidneyshaped to ovoid sporangioles. Fruiting bodies on the agar surface commonly develop as chains of sporangioles laid down and partially overlapping each other like shingles or roof tiles, and the series tapered to one end. Growth was initially relatively slow and bacterial contaminants adhering to the tough and slimy swarm grew faster, making repeated transfer of the swarm edge necessary to isolate the novel strain in pure culture. Final transfers onto water agar with a spot of autoclaved Escherichia coli culture still gave slow growth and, finally, complete cell lysis after 3-4 weeks of incubation. Better growth was detected on MCA $(0.1 \%$ each of Bacto casitone, $\mathrm{CaCl}_{2} \cdot 2 \mathrm{H}_{2} \mathrm{O}$ and $\mathrm{MgSO}_{4} \cdot 7 \mathrm{H}_{2} \mathrm{O}, 10 \mu \mathrm{g}$ vitamin $\mathrm{B}_{12} \mathrm{ml}^{-1}, 1.12 \%$ Bacto agar). Live food bait (E. coli) quickly induced swarming. The advancing vegetative cells cleared the bait and left behind massive clusters of golden-yellow fruiting bodies. The swarm colonies resembled those of members of the Cystobacteraceae, but with vegetative cells typical of the Polyangiaceae. Only Kofleria flava of the Kofleriaceae in the suborder Nannocystineae is known for this growth pattern (Reichenbach, 2005). 
Another isolate, which we designate as a reference strain, was isolated in July 1988 from a soil sample with plant residues collected in the Etosha Basin in Namibia. Previously known as NOSO-1 (New organism of the Sorangiineae type strain 1) (Spröer et al., 1999; Reichenbach et al., 2006), it has the same morphological characteristics as the Philippine strain $\mathrm{SBKo001}{ }^{\mathrm{T}}$.

Media and cultivation. Strains $\mathrm{SBKo} 001^{\mathrm{T}}$ and NOSO-1 were routinely cultivated and maintained on VY/2 and MD1 agar media (Shimkets et al., 2006) supplemented with $0.35 \%$ L-arabinose (Acros). Both solid and liquid media used in this study were adjusted to $\mathrm{pH} 7.2$ with $\mathrm{KOH}$ before autoclaving.

Morphological observations. Swarming colonies and fruiting bodies were observed under an Olympus SH-ILLB stereoscopic microscope and photographed using an Axiocam MRC (Zeiss) camera. Fruiting bodies were also analysed using laser scanning fluorescent microscopy (CLSM-510META; Carl Zeiss). Vegetative cell morphology and myxospores were studied using phase-contrast microscopy (Leitz). All growth stages were observed on agar media PM-12 (Kopp et al., 2004), MCA, MD1 and VY/2.

Physiological tests. Reactions of vegetative cells to Gram and Congo red stains were determined; staining with the latter was after the method of McCurdy (1969). Catalase was tested with $3.0 \% \mathrm{H}_{2} \mathrm{O}_{2}$. Cellulose degradation was examined using MCA, VY/2 and ST21 agar (Shimkets et al., 2006), all overlaid with filter paper $(2 \times 1 \mathrm{~cm})$, and in parallel runs on Cel-3 agar (Reichenbach \& Dworkin, 1992) to determine degradation of cellulose powder. The degradation assay for chitin was done using CT-6 and CT-7 agar (Reichenbach, 2006) and, for agar (Bacto), with VY/2 agar, MCA (baited with autoclaved E. coli) and MD1 agar.

Microbial predation tests. Overnight cultures of the bacteria E. coli (Gram-negative) and Micrococcus luteus (Gram-positive) and yeasts Hansenula anomala and Saccharomyces cerevisiae were spot-inoculated on MCA close to the edge of 5-day-old active vegetative cells previously washed twice with sterile distilled water (centrifugation at 10000 r.p.m. for $1 \mathrm{~min}$ at room temperature). Spots of bacterial and yeast bait approximately $10 \mathrm{~mm}$ in diameter were air-dried for a few minutes before culture plates were sealed with Parafilm and incubated at $30{ }^{\circ} \mathrm{C}$ for $2-3$ weeks. Clearing of the microbial food baits indicated lytic action by the spreading myxobacterial swarm.

Growth responses to temperature, carbon and nitrogen sources and antibiotics. Tests for growth responses to different temperatures were done with MD1 agar and, for antibiotic resistance, with MD1 and VY/2 agar. Vegetative cell inocula came from liquid versions of the same culture media but washed twice with equal volumes of sterile distilled water and collected by centrifugation at 10000 r.p.m. for $1 \mathrm{~min}$. Antibiotics used were apramycin (Fluka), ampicillin, kanamycin, hygromycin B (Roth), tobramycin (Sigma), spectinomycin (Serva), tetracycline, oxytetracycline, streptomycin (Synopharm) and gentamicin (Applichem), all filter-sterilized and added after autoclaving of the medium.

Utilization of nitrogenous compounds was analysed using minimal medium (CM agar: $0.07 \% \mathrm{CaCl}_{2} .2 \mathrm{H}_{2} \mathrm{O}, 0.2 \% \mathrm{MgSO}_{4} .7 \mathrm{H}_{2} \mathrm{O}$, $0.01 \%$ HEPES, $1.5 \%$ agar) individually supplemented with $10 \mathrm{mM}$ L-aspartic acid, L-glutamic acid, urea, $\mathrm{KNO}_{3}$ and $\left(\mathrm{NH}_{4}\right)_{2} \mathrm{SO}_{4}$. Also tested were milk casein agar $[0.5 \%$ milk casein (Sigma), $0.15 \%$ yeast extract, $1.5 \%$ agar] and skimmed milk agar [SKM: $15 \mathrm{~g}$ skimmed milk (Oxoid) in $60 \mathrm{ml}$ distilled water, autoclaved separately and mixed with $300 \mathrm{ml} \mathrm{CY}$ agar (Shimkets et al., 2006)], tryptone broth $\left(0.3 \%\right.$ tryptone, $0.1 \% \mathrm{CaCl}_{2} .2 \mathrm{H}_{2} \mathrm{O}, 0.1 \%$ $\left.\mathrm{MgSO}_{4} \cdot 7 \mathrm{H}_{2} \mathrm{O}\right)$ and phytone broth $(0.3 \%$ phytone, $0.1 \%$ $\mathrm{CaCl}_{2} \cdot 2 \mathrm{H}_{2} \mathrm{O}, 0.1 \% \mathrm{MgSO}_{4} \cdot 7 \mathrm{H}_{2} \mathrm{O}$ ).
Carbon sources tested were fructose, D-mannose, sucrose and Larabinose, D-glucose, D-galactose, sorbitol, cellobiose, molasses in MD1 broth, soluble starch in Amb lm broth and STK2 agar (Shimkets et al., 2006), maltose in M medium (Müller \& Gerth, 2006) and xylan in XYL3 agar [0.5\% xylan (Serva), $0.05 \%\left(\mathrm{NH}_{4}\right)_{2} \mathrm{SO}_{4}, 1.5 \%$ agar] overlay as a thin layer on CYG2 agar (Shimkets et al., 2006). Also tested were common media like CTT, CY (Shimkets et al., 2006) and P medium ( $0.2 \%$ peptone, $0.8 \%$ soluble starch, $0.4 \%$ Probion, $0.2 \%$ yeast extract, $0.1 \% \mathrm{CaCl}_{2}, 0.1 \% \mathrm{MgSO}_{4}, 100 \mathrm{mM}$ HEPES, $8 \mathrm{mg}$ ferric EDTA $1^{-1}, \mathrm{pH}$ 7.5).

Incubation for all tests was performed for $2-3$ weeks at $30{ }^{\circ} \mathrm{C}$ except for the temperature response at 18 and $37^{\circ} \mathrm{C}$.

Fatty acid and DNA G+C content analyses. Cell pellets were prepared from 2-week-old actively growing vegetative cell liquid cultures (MD1A, optimal medium with $0.35 \%$ arabinose). Analysis of cellular fatty acids was performed by GC-MS according to the methods of Bode et al. (2006) and Ring et al. (2006). The DNA G +C content of the novel bacterium was determined by HPLC ( $\mathrm{Li}$ et al., 2003; Shimelis \& Giese, 2006).

$16 S$ rRNA gene sequencing and phylogenetic analyses. Genomic DNA was extracted from actively growing cells using the protocol for Gram-negative bacteria of the Puregene genomic DNA purification kit (Gentra). Aliquots of DNA were prepared for PCR using forward and reverse primers as described previously (Lachnik et al., 2002). These primers were also used for sequencing of the PCR products. Purification of the PCR product was performed using the NucleoSpin kit (Macherey-Nagel). The sequence obtained was compared to the NCBI BLAST nucleotidenucleotide database. Sequence alignments were created using CLUSTAL_X (Thompson et al., 1997) and edited manually. Distance matrices between sequences were calculated using the F84 parameter model of the DNADIST program in the PHYLIP package version 3.67 (Felsenstein, 2002). From the distance matrices, a neighbour-joining tree was constructed using the same package. A bootstrap of 100 replicates was designed using SEQBOOT. Finally, construction of consensus trees was performed using the CONSENSE program found in the same package. The sequence of the reference strain NOSO-1 from GenBank was included in the phylogenetic tree analysis.

\section{RESULTS AND DISCUSSION}

\section{Morphological and cultural characteristics}

Swarm. Growth was initially slow, even after weeks of incubation, but improved as the strain became adapted after successive transfers. Colonies on the agar were tough, slimy, spreading swarms with long, fine, radial veins (Supplementary Fig. S1a), a feature regarded as typical for the family Cystobacteraceae but also seen in Kofleria. On VY/2 agar, the swarm was whitish to cream-coloured and less slimy. Movement was coherent, with the vegetative cells massing at the colony edge to form a reticulum with flame-like outward extensions; this swarm pattern differs from that of Polyangium, where swarm edges are made of rolls of cells. Behind were long radial veins that often became deserted as cells migrated distally. Unlike Cystobacter and Archangium, clearing of yeast on VY/2 agar was not observed. On PM-12 agar with E. coli, swarm veins were longer, finer and less transparent (Supplementary Fig. S1b) but still with the peripheral 


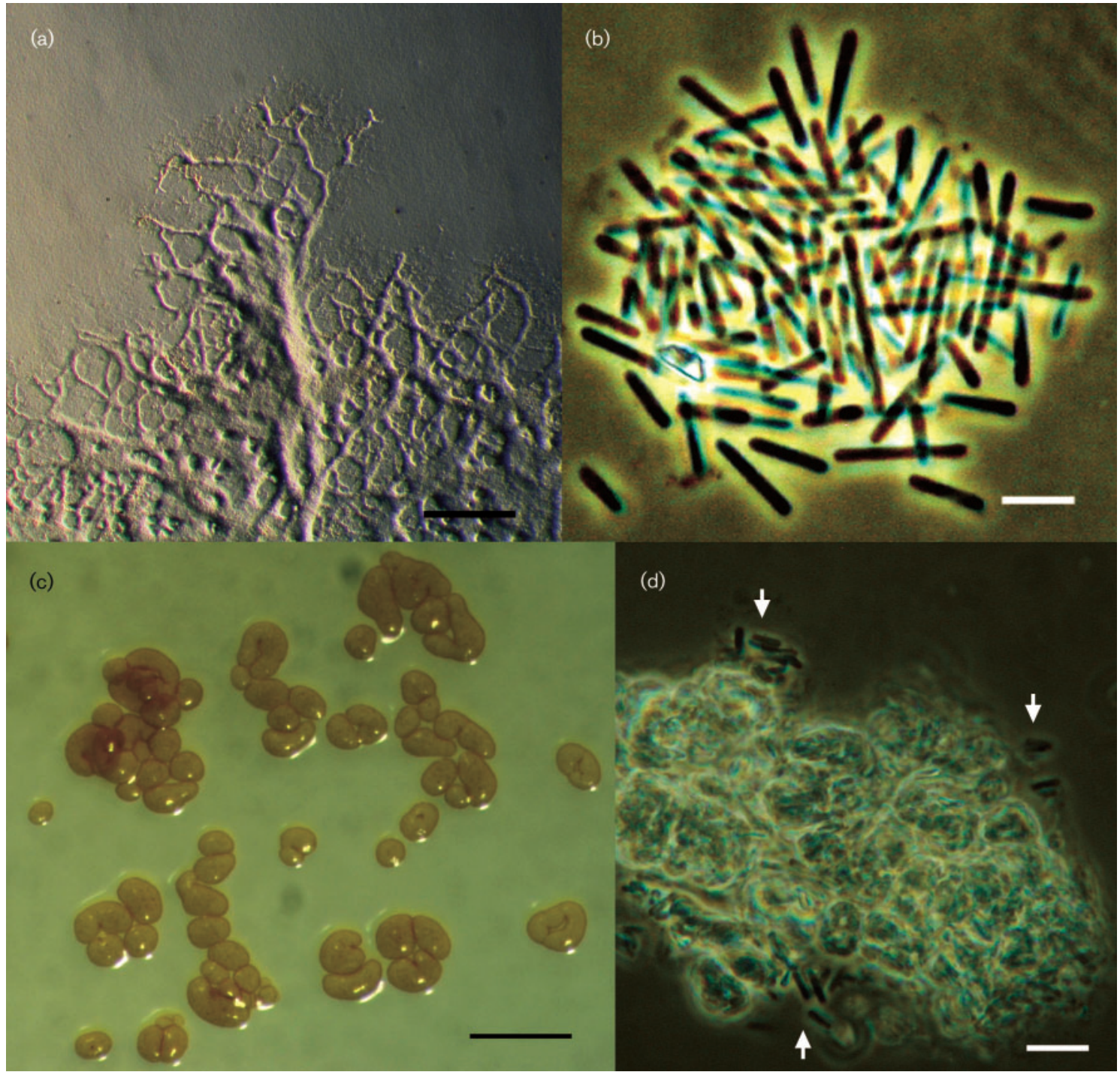

Fig. 1. Growth stages of strain $\mathrm{SBKo001^{ \top }}$ on MCA agar. (a) Stereoscopic photomicrograph of swarm colony. (b) Phasecontrast photomicrograph of vegetative cells. (c) Golden-yellow fruiting bodies. (d) Phase-contrast photomicrograph of myxospores (arrows) from crushed sporangioles. Bars, $400 \mu \mathrm{m}$ (a), $10 \mu \mathrm{m}$ (b, d) and $250 \mu \mathrm{m}$ (c).

flame-like outgrowths (Supplementary Fig. S1c) characteristic of the Myxococcaceae and Cystobacteraceae. The same growth pattern was found on MCA except that there were more adventurous solitary cells scattered at the edge of the colony (Fig. 1a); on the same medium with an E. coli spot, the distal reticulations with flame-like swarm ends were even more remarkable. Growth on MD1 agar showed the same swarm pattern but turned thicker and slimier after 5 days at $30{ }^{\circ} \mathrm{C}$. Migrating swarm cells produced no diffusible pigment in any tested medium and, unlike in Myxococcus stipitatus, did not fluoresce under UV light (Lampky \& Brockman, 1977). Shallow depressions or corrosions of the agar surface were present at late stages of growth.

Vegetative cells. The vegetative cells in slide mounts were long rods (Fig. 1b) measuring 1.0-1.5 ×3.5-10.5 $\mu \mathrm{m}$. Ends of the cells are rounded, typical of the suborder Sorangiineae. Motility was by gliding on the agar surface. Near the poles of the cells were dark spots (Supplementary Fig. S2) that may be hypothesized to represent polyphosphate (Voelz et al., 1966). In Sorangium, it was speculated that these spots are lipid material (Lampky, 1976).

Fruiting bodies. Fruiting bodies are composed of goldenyellow sporangioles that varied in shape, size and arrangement depending on the growth medium. On MCA with E. coli bait, sporangioles started to develop along the bait after 3 days at $30{ }^{\circ} \mathrm{C}$; mature ones were typically kidney-shaped, glistening and arranged in monolayer clusters (Fig. 1c). Sporangioles also appeared in chains, the largest and the smallest at or near opposite ends of the series (Fig. 2), somewhat resembling 


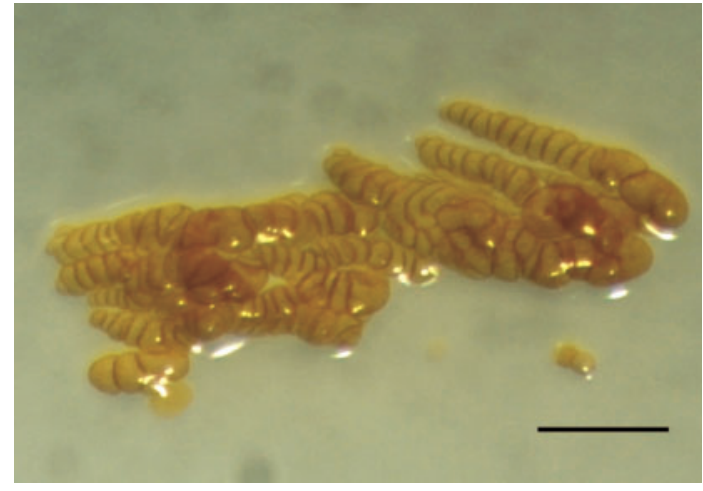

Fig. 2. Fruiting bodies of strain $\mathrm{SBKoO01^{ \top }}$ arranged in chains. Bar, $700 \mu \mathrm{m}$.

degenerating fruiting bodies of Hyalangium strains (Reichenbach, 2005). Rarely, they appeared solitary and, in these cases, were usually located within the agar. Sporangiole walls were thick and appeared double-layered (Supplementary Fig. S3). On yeast agar (VY/2), fruiting bodies started to appear on the fifth day at $30{ }^{\circ} \mathrm{C}$. These were reminiscent of Sorangium: compact clusters or sori $(32-52 \times 86-193 \mu \mathrm{m})$ (Supplementary Fig. S4) of tiny, pale-yellow, ovoid sporangioles $(20-25 \times 49-56 \mu \mathrm{m})$.

Myxospores. Crushed sporangioles released tightly packed, optically refractive rod cells which we presumed to be myxospores (Fig. 1d). These were shorter than but nearly as wide as vegetative cells $(1.0-1.2 \times 3.2-4.0 \mu \mathrm{m})$, with rounded ends.

\section{Physiological characteristics}

Staining and lytic property. Vegetative cells are Gramnegative and catalase-positive. The swarm colony was unstained with Congo red, as with the Sorangiineae, although exhibiting Cystobacteraceae-type morphology. The bacterial food bait (E. coli) on MCA was slowly and eventually completely lysed. In contrast, live Micrococcus luteus and the unicellular yeasts $H$. anomala and $S$. cerevisiae were hardly degraded even after months of incubation. However, growth on yeast (VY/2) agar was vigorous, probably due to leached nutrients.

SBKo001 $1^{\mathrm{T}}$ and NOSO-1 differ from Sorangium and Byssovorax by their inability to degrade cellulose on Cel-3 and ST21 agar overlaid with filter paper. Chitin powder on CT-7 agar was not degraded by the advancing swarm cells even after months of incubation. Unlike Nannocystis- and Polyangiaceae-type advancing swarm cells, which produce deep caverns and holes on agar medium (Reichenbach \& Dworkin, 1992), those of SBKo001 $1^{\mathrm{T}}$ and NOSO-1 formed only very shallow depressions, noticeable only after more than 3 weeks of cultivation on VY/2 agar and MCA.
Temperature responses. On MD1 agar, optimal growth with the fastest colony spreading and largest swarm diameter was seen at $30{ }^{\circ} \mathrm{C}$. Colony diameter was small at $37{ }^{\circ} \mathrm{C}$. No growth occurred at $18{ }^{\circ} \mathrm{C}$.

Carbon sources. Sucrose, fructose, D-mannose and Larabinose at $0.35 \%(\mathrm{w} / \mathrm{v})$ in MD1 broth gave good growth, with L-arabinose yielding the highest cell mass. Growth was moderate with maltose, glucose and molasses, also at $0.35 \%$, and negative with $1.0 \%$ maltose in $\mathrm{M}$ medium. Cellobiose, D-galactose, sorbitol and soluble starch all yielded poor growth, and soluble starch at $0.5 \%$ in Amb $\mathrm{lm}$ medium gave no growth. Surprisingly, there was growth on starch agar (STK2), with the development of a large silky swarm with typical radial vein pattern; flooded with iodine, only the swarm centre remained unstained, indicating weak starch hydrolysis. Slight xylan decomposition was also observed on XYL3 agar.

Nitrogen sources. Fast swarm colonies were evident on CMA with aspartic acid within only 2 days at $30{ }^{\circ} \mathrm{C}$, and these culminated in fruiting body formation. Supply of glutamic acid on CMA resulted in cell death. Moderate growth up to cell aggregation occurred in as little as 2 days with $\mathrm{KNO}_{3}$ and urea, but with failure of fruiting even after months of extended incubation. With $\left(\mathrm{NH}_{4}\right)_{2} \mathrm{SO}_{4}$, only swarms with small diameters were formed. In contrast, both inorganic nitrogen sources in VY/2 agar induced a complete developmental cycle with characteristic highdensity fruiting bodies. VY/2 agar seems to provide all the requirements for growth and development, so much so that the growth cycle was complete even without the addition of an inorganic nitrogen source. Moreover, all other tested nitrogen sources, including glutamic acid, gave good growth when incorporated in the same agar medium.

M medium supports optimal growth for many Sorangium strains (Müller \& Gerth, 2006) but not for the novel strain. Phytone at $1.0 \%$ in $\mathrm{M}$ medium gave no growth and, at $0.3 \%$ in phytone broth in shake culture, yielded only a few small clumps of cells. Neither could the novel strain grow in the complex P medium with $0.2 \%$ peptone. The rich CTT medium with $1.0 \%$ casitone, known to provide optimum growth for Myxococcus xanthus, showed an opposite effect on the novel strain. Even reducing the casitone content to $0.3 \%$ in $\mathrm{CY}$, TY, tryptone broth and MD1 gave only yellow, clumpy cell masses after weeks of shake cultivation. A translucent zone was produced on agar with milk casein, indicating complete breakdown. Moderate swarm colonies formed on SKM agar, but no fruiting bodies developed. The complex liquid media HS and PM-12 with both organic (peptone from casein) and inorganic $\left(\mathrm{KNO}_{3}\right)$ nitrogen sources, known to provide optimal growth for Sorangium strains (Kopp et al., 2004), provided only minimal and dispersed growth for the novel strain.

Antibiotic resistance. $\mathrm{SBKo} 001^{\mathrm{T}}$ and NOSO-1 were sensitive to oxytetracyline, tetracycline and ampicillin, 
but resistant to nearly all other tested antibiotics at $50 \mu \mathrm{g}$ $\mathrm{ml}^{-1}$ on MD1 and VY/2 agar incubated for 2-5 days at $30{ }^{\circ} \mathrm{C}$. Growth in kanamycin and spectinomycin was poor, with the swarm hardly visible macroscopically due to the shortening of vegetative cells. This contrasts with resistance to 10 and $1000 \mu \mathrm{g}$ kanamycin $\mathrm{ml}^{-1}$ reported for Byssovorax and Sorangium strains, respectively (Reichenbach et al., 2006). With streptomycin, the swarm colony diameter was moderate, but the swarm colony was thin and less slimy. Swarms with typical architecture developed on agar media with aminoglycoside (gentamicin, apramycin, tobramycin, kanamycin) and aminocyclitol (spectinomycin and hygromycin B) antibiotics, indicating that these drugs do not affect protein synthesis in either $\mathrm{SBKo} 001^{\mathrm{T}}$ or NOSO1. On the other hand, sensitivity to ampicillin may indicate vulnerability of their cell envelope to the agent.

Fatty acid and DNA $\mathbf{G}+\mathrm{C}$ content analyses. SBKo $001^{\mathrm{T}}$ showed the highest percentage of the branched-chain fatty acid iso- $\mathrm{C}_{15: 0}$ (Table 1), which is characteristic for most myxobacteria. A significant amount of $\mathrm{C}_{17: 1} \quad 2-\mathrm{OH}$ $(25.19 \%)$ was also found. Also detected was the longchain polyunsaturated fatty acid (PUFA) $\mathrm{C}_{20: 4}(12.44 \%)$, identified as arachidonic acid using pure reference substance as control. NOSO-1 contains nearly three times as much of this fatty acid (35.7\%). To our knowledge, this is the first report of $\omega-6$ fatty acids in myxobacteria. These

Table 1. Cellular fatty acid profiles of strains $\mathrm{SBKoO01}{ }^{\top}$ and NOSO-1

Values are percentages of total fatty acids. -, Not detected.

\begin{tabular}{|c|c|c|}
\hline Fatty acid & $\mathrm{SBKo001}^{\mathrm{T}}$ & NOSO-1 \\
\hline \multicolumn{3}{|l|}{ Straight-chain } \\
\hline $\mathrm{C}_{14: 0}$ & 0.73 & - \\
\hline $\mathrm{C}_{16: 0}$ & 6.01 & 12.71 \\
\hline $\mathrm{C}_{17: 0}$ & 5.53 & - \\
\hline $\mathrm{C}_{18: 0}$ & 3.22 & 2.23 \\
\hline $\mathrm{C}_{20: 4}$ & 12.44 & 35.71 \\
\hline \multicolumn{3}{|l|}{ Branched-chain } \\
\hline iso- $\mathrm{C}_{15: 0}$ & 25.52 & 7.94 \\
\hline iso- $\mathrm{C}_{17: 0}$ & 3.71 & 19.64 \\
\hline \multicolumn{3}{|l|}{ Hydroxy } \\
\hline $\mathrm{C}_{16: 0} 2-\mathrm{OH}$ & 0.08 & - \\
\hline $\mathrm{C}_{16: 1} 2-\mathrm{OH}$ & 1.69 & 2.85 \\
\hline $\mathrm{C}_{17: 0} 2-\mathrm{OH}$ & 6.57 & - \\
\hline $\mathrm{C}_{17: 1} 2-\mathrm{OH}$ & 25.19 & 6.56 \\
\hline $\mathrm{C}_{18: 0} 2-\mathrm{OH}$ & 0.32 & - \\
\hline $\mathrm{C}_{18: 1} 2-\mathrm{OH}$ & 1.81 & - \\
\hline \multicolumn{3}{|c|}{ Branched-chain hydroxy } \\
\hline iso- $\mathrm{C}_{17: 0} 2-\mathrm{OH}$ & 0.16 & - \\
\hline iso- $\mathrm{C}_{17: 1} 2-\mathrm{OH}$ & 1.89 & 1.38 \\
\hline \multicolumn{3}{|l|}{ O-Alkylglycerols } \\
\hline $\mathrm{C}_{14: 0}$ & 0.79 & - \\
\hline $\mathrm{C}_{15: 0}$ & 1.43 & 0.53 \\
\hline $\mathrm{C}_{16: 0}$ & 2.92 & 10.43 \\
\hline
\end{tabular}

unsaturated fatty acids are also known to be produced by some gliding but non-fruiting marine bacteria (Hosoya et al., 2006). The amount of PUFA in NOSO-1 is approximately the same as reported for the zygomycetous fungus Mortierella alpina (40\%; Wynn et al., 1999). The marine myxobacteria Plesiocystis pacifica and Enhygromyxa salina were also discovered to produce an unidentified $\mathrm{C}_{20: 4}$ PUFA (Iizuka et al., 2003a, b). It is also rarely found in other bacteria and seems to be produced in small $(<1 \%)$ amounts (Nichols et al., 1997). The DNA G+C content of strain $\mathrm{SBKo} 001^{\mathrm{T}}$ is $69.2 \mathrm{~mol} \%$.

Phylogenetic analysis. The $16 \mathrm{~S}$ rRNA gene sequence of SBKo001 ${ }^{\mathrm{T}}$ shows $100 \%$ identity to that of the reference strain NOSO-1, which was previously referred to as an unidentified myxobacterium. The next highest similarity (94\%) was found to the cellulose-degrading strains Sorangium (Polyangium) cellulosum So02007-3 (GenBank accession no. AY252114; not shown in Fig. 3) and Byssovorax ('Byssophaga') cruenta DSM $14553^{\mathrm{T}}$. Strains SBKo001 $1^{\mathrm{T}}$ and NOSO-1 form a distinct cluster under the suborder Sorangiineae (Fig. 3). This confirms earlier phylogenetic studies (Reichenbach et al., 2006; Spröer et al., 1999) showing NOSO-1 as an independent branch of the Sorangiineae, divergent from the family Polyangiaceae, and hypothesized to constitute a new genus (Spröer et al., 1999). The significant difference in $16 \mathrm{~S}$ rRNA gene sequence from the Polyangiaceae (as represented by Sorangium and Byssovorax) and the branching out from that group indicate that strains $\mathrm{SBKo} 001^{\mathrm{T}}$ and NOSO-1 represent not only a novel genus and species, Phaselicystis flava gen. nov., sp. nov., but also a new family, Phaselicystidaceae fam. nov.

\section{Description of Phaselicystis gen. nov. Garcia, Reichenbach and Müller}

Phaselicystis (Pha.se.li.cys'tis. L. masc. n. phaselos an edible bean, kidney bean; Gr. fem. n. cystis bladder; N.L. fem. n. Phaselicystis bean-shaped bladder, pertaining to the shape of the sporangiole).

Vegetative cells are long and cylindrical rods with blunt ends typical of the Polyangiaceae; movement by gliding on the agar surface in long and fine radial veins. The swarm is tough, film-like and slimy, characteristic of the Cystobacteraceae. Colonies are Congo-red-negative, with edges with sophisticated networking of migrating cells on lean media; the agar is slightly etched and corroded. Myxospores are refractive, slender rods, shorter than vegetative cells, enclosed in a sporangial wall. Fruiting bodies are ovoid to sausage- or bean-shaped, glistening sporangioles that are clustered in chains or a flat mat, or solitary. Yeast is not degraded. Exhibit a bacteriolytic type of nutrition. Contain straight-chain $\mathrm{C}_{20: 4}$ (arachidonic acid). 16S rRNA gene sequence analysis indicates independent branching from the Polyangiaceae in the suborder Sorangiineae. The DNA G $+C$ content of the type strain of 


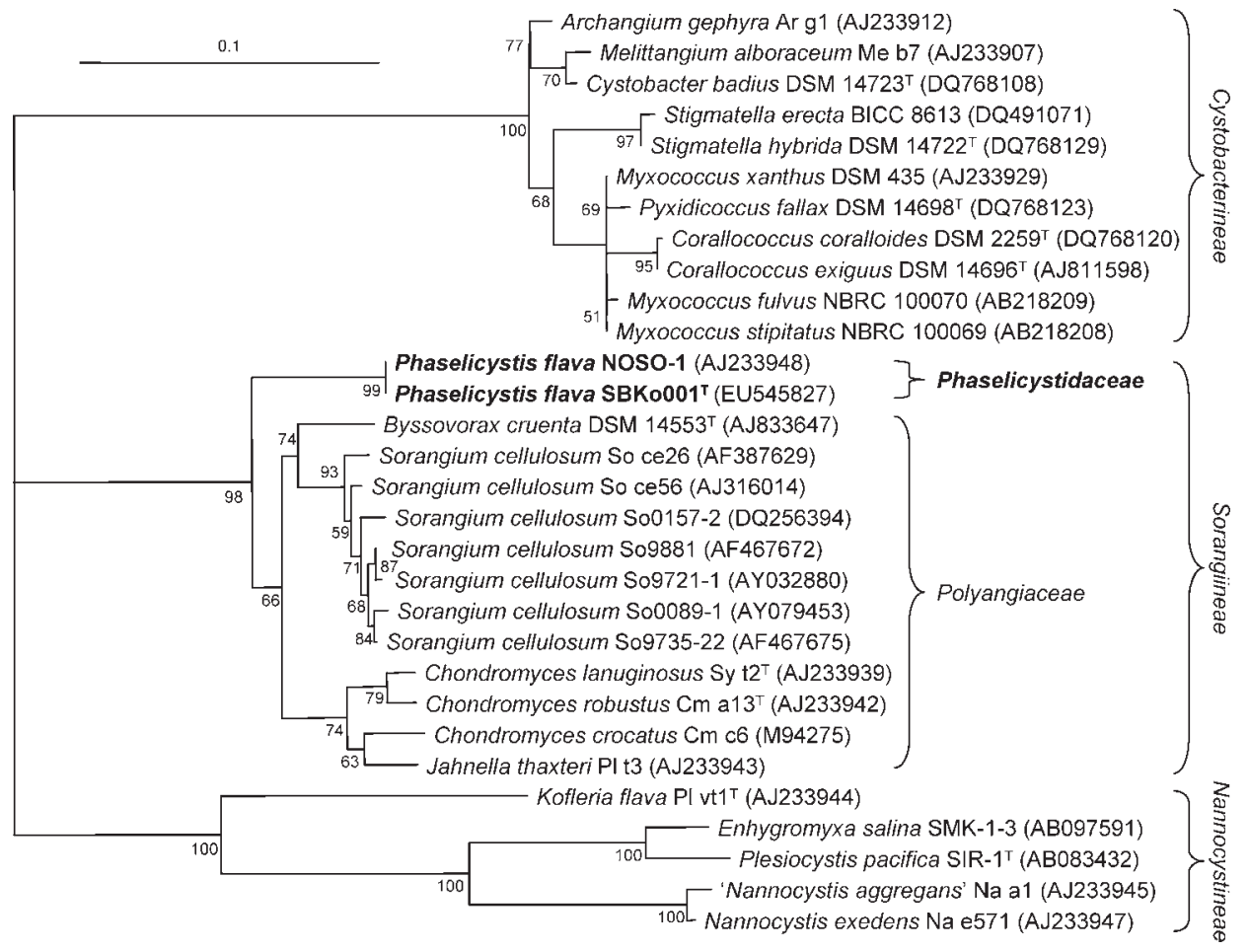

Fig. 3. Neighbour-joining tree based on $16 \mathrm{~S}$ rRNA gene sequences showing the phylogenetic position of strains $\mathrm{SBKo001}{ }^{\top}$ and NOSO-1. Bar, 0.1 substitutions per nucleotide position.

the type species is $69.2 \mathrm{~mol} \%$. The type species is Phaselicystis flava.

\section{Description of Phaselicystis flava sp. nov. Garcia, Reichenbach and Müller}

Phaselicystis flava (fla'va. L. fem. adj. flava golden-yellow).

Displays all the characteristics of the genus. In addition, vegetative cells are fat rods, $1.0-1.5 \times 3.5-10.5 \mu \mathrm{m}$, and phase dark. Swarms of tough and radial veins only on the surface of the agar, with flame-like peripheral extensions formed by migrating cells; shallow depressions evident in old cultures. Fruiting bodies induced by microbial food bait, as goldenyellow, monolayered clusters on MCA spotted with E. coli and as sori $(32-86 \times 52-193 \mu \mathrm{m})$ of tightly packed sporangioles $(20-49 \times 25-56 \mu \mathrm{m})$ on VY/2 agar. Myxospores are stout and short rods $(1.0-1.2 \times 3.2-4.0 \mu \mathrm{m})$, with rounded ends like vegetative cells; enclosed in thick, golden-yellow sporangial wall. Cellulose and chitin are not degraded. Good growth in sucrose, fructose, D-mannose and L-arabinose. Resistant to aminoglycoside antibiotics gentamicin, apramycin, tobramycin and kanamycin and structurally related aminocyclitols spectinomycin and hygromycin B. Sensitive to ampicillin, tetracycline and oxytetracycline. Major cellular fatty acid components are iso- $\mathrm{C}_{15: 0}, \mathrm{C}_{17: 1} 2-\mathrm{OH}$ and $\mathrm{C}_{20: 4}$.

The type strain is $\mathrm{SBKo} 001^{\mathrm{T}}\left(=\mathrm{DSM} 21295^{\mathrm{T}}=\mathrm{NCCB}\right.$ $100230^{\mathrm{T}}$ ), isolated from a soil sample collected in the
Philippines (Mt Makiling Forest Reserve, Laguna Province) in December 2006. Strain NOSO-1 (=DSM 53757), isolated in July 1988 from a soil sample in Etosha Basin, Namibia (Spröer et al., 1999; Reichenbach et al., 2006), is a reference strain.

\section{Description of Phaselicystidaceae fam. nov. Garcia, Reichenbach and Müller}

Phaselicystidaceae (Pha.se.li.cys.ti.da'ce.ae. N.L. fem. n. Phaselicystis type genus of the family; L. suff. -aceae ending to denote a family; N.L. pl. fem. n. Phaselicystidaceae the Phaselicystis family).

Soil myxobacteria. Vegetative cells represent long cylindrical, Gram-negative rods with rounded ends. Swarm colonies with long and fine radial vein pattern, produced typically on agar surface, do not adsorb Congo red stain. Fruiting bodies consist of sporangioles. Myxospores are optically refractive, short, cylindrical rods. Bacteriolytic nutritional type. Do not degrade cellulose or chitin. Contain cellular arachidonic acid. The type genus is Phaselicystis.

\section{ACKNOWLEDGEMENTS}

We thank Dr Holger Jenke-Kodama and Dr Olena Perlova for valuable help and suggestions in 16S rRNA gene and phylogenetic tree analyses and we acknowledge Professor Dr Irineo J. Dogma, Jr (University of Santo Tomas, Graduate School, Manila, Philippines), for excellent technical assistance. Research in the laboratory of R. M. 
was funded by the Deutsche Forschungsgemeinschaft (DFG) and the Bundesministerium für Bildung und Forschung (BMBF).

\section{REFERENCES}

Bode, H. B., Ring, M. W., Schwär, G., Kroppenstedt, R. M., Kaiser, D. \& Müller, R. (2006). 3-Hydroxy-3-methylglutaryl-coenzyme A (CoA) synthase is involved in the biosynthesis of isovaleryl-CoA in the myxobacterium Myxococcus xanthus during fruiting body formation. J Bacteriol 188, 6524-6528.

Brazill, D. \& Gomer, R. (2007). A eukaryotic neighbor: Dictyostelium discoideum. In Myxobacteria: Multicellularity and Differentiation, pp. 439-452. Edited by D. E. Whitworth. Washington, DC: American Society for Microbiology.

Felsenstein, J. (2002). PHYLIP (phylogeny inference package) version 3.67. Distributed by the author. Department of Genome Sciences, University of Washington, Seattle, USA.

Hosoya, S., Arunpairojana, V., Suwannachart, C., Kanjana-Opas, A. \& Yokota, A. (2006). Aureispira marina gen. nov., sp nov., a gliding, arachidonic acid-containing bacterium isolated from the southern coastline of Thailand. Int J Syst Evol Microbiol 56, 2931-2935.

lizuka, T., Jojima, Y., Fudou, R., Hiraishi, A., Ahn, J.-W. \& Yamanaka, S. (2003a). Plesiocystis pacifica gen. nov., sp. nov., a marine myxobacterium that contains dihydrogenated menaquinone, isolated from the Pacific coasts of Japan. Int J Syst Evol Microbiol 53, 189-195.

lizuka, T., Jojima, Y., Fudou, R., Tokura, M., Hiraishi, A. \& Yamanaka, S. (2003b). Enhygromyxa salina gen. nov., sp. nov., a slightly halophilic myxobacterium isolated from the coastal areas of Japan. Syst Appl Microbiol 26, 189-196.

Kopp, M., Irschik, H., Gross, F., Perlova, O., Sandmann, A., Gerth, K. \& Müller, R. (2004). Critical variations of conjugational DNA transfer into secondary metabolite multiproducing Sorangium cellulosum strains So ce12 and So ce56: development of a mariner-based transposon mutagenesis system. J Biotechnol 107, 29-40.

Lachnik, J., Ackermann, B., Bohrssen, A., Maass, S., Diephaus, C., Punken, A., Stermann, M. \& Bange, F.-C. (2002). Rapid-cycle PCR and fluorimetry for detection of mycobacteria. J Clin Microbiol 40, 3364-3373.

Lampky, J. R. (1976). Ultrastructure of Polyangium cellulosum. J Bacteriol 126, 1278-1284.

Lampky, J. R. \& Brockman, E. R. (1977). Fluorescence of Myxococcus stipitatus. Int J Syst Bacteriol 27, 161.

Li, G., Shimelis, O., Zhou, X. \& Giese, R. W. (2003). Scaled-down nuclease P1 for scaled-up DNA digestion. Biotechniques 34, 908-909.

McCurdy, H. D. (1969). Studies on taxonomy of the Myxobacterales. I. Record of Canadian isolates and survey of methods. Can J Microbiol $15,1453-1461$.
Müller, R. \& Gerth, K. (2006). Development of simple media which allow investigations into the global regulation of chivosazol biosynthesis with Sorangium cellulosum So ce56. J Biotechnol 121, 192-200.

Nichols, D. S., Brown, J. L., Nichols, P. D. \& McMeekin, T. A. (1997). Production of eicosapentaenoic and arachidonic acids by an Antarctic bacterium: response to growth temperature. FEMS Microbiol Lett 152, 349-354.

Reichenbach, H. (2005). Order VIII. Myxococcales Tchan, Pochon and Prévot 1948, 398 ${ }^{\mathrm{AL}}$. In Bergey's Manual of Systematic Bacteriology, 2nd edn, vol. 2, part C, pp. 1059-1072. Edited by D. J. Brenner, N. R. Krieg, J. T. Staley \& G. M. Garrity. New York: Springer.

Reichenbach, H. (2006). The genus Lysobacter. In The Prokaryotes: a Handbook on the Biology of Bacteria, 3rd edn, vol. 6, pp. 939-957. Edited by M. Dworkin, S. Falkow, E. Rosenberg, K. H. Schleifer \& E. Stackebrandt. New York: Springer.

Reichenbach, H. \& Dworkin, M. (1992). The myxobacteria. In The Prokaryotes, 2nd edn, pp. 3416-3487. Edited by A. Balows, H. G. Trüper, M. Dworkin, W. Harder \& K. H. Schleifer. New York: Springer.

Reichenbach, H., Lang, E., Schumann, P. \& Spröer, C. (2006). Byssovorax cruenta gen. nov., sp nov., nom. rev., a cellulose-degrading myxobacterium: rediscovery of 'Myxococcus cruentus' Thaxter 1897. Int J Syst Evol Microbiol 56, 2357-2363.

Ring, M. W., Schwär, G., Thiel, V., Dickschat, J. S., Kroppenstedt, R. M., Schulz, S. \& Bode, H. B. (2006). Novel iso-branched ether lipids as specific markers of developmental sporulation in the myxobacterium Myxococcus xanthus. J Biol Chem 281, 36691-36700.

Shimelis, O. \& Giese, R. (2006). Nuclease P1 digestion/highperformance liquid chromatography, a practical method for DNA quantitation. J Chromatogr A 1117, 132-136.

Shimkets, L. J., Dworkin, M. \& Reichenbach, H. (2006). The myxobacteria. In The Prokaryotes: a Handbook on the Biology of Bacteria, 3rd edn, vol. 7, pp. 31-115. Edited by M. Dworkin, S. Falkow, E. Rosenberg, K. H. Schleifer \& E. Stackebrandt. New York: Springer.

Spröer, C., Reichenbach, H. \& Stackebrandt, E. (1999). The correlation between morphological and phylogenetic classification of myxobacteria. Int J Syst Bacteriol 49, 1255-1262.

Thompson, J. D., Plewniak, T. J., Jeanmougin, F. \& Higgins, D. G. (1997). The CLUSTAL_X windows interface: flexible strategies for multiple sequence alignment aided by quality analysis tools. Nucleic Acids Res 25, 4876-4882.

Voelz, H., Voelz, U. \& Ortigoza, R. O. (1966). The "polyphosphate overplus" phenomenon in Myxococcus xanthus and its influence on the architecture of the cell. Arch Mikrobiol 53, 371-388.

Wynn, J. P., Hamid, A. A. \& Ratledge, C. (1999). The role of malic enzyme in the regulation of lipid accumulation in filamentous fungi. Microbiology 145, 1911-1917. 